\title{
STATE LIABILITY VIS-À-VIS VICTIMS OF CRIME IN POST-1994 SOUTH AFRICAN CASE LAW - SOMETHING NEW OR A REINVENTED WHEEL?
}

\author{
John $C$ von Bonde \\ BJuris LLB LLD \\ Senior Lecturer in Law \\ Nelson Mandela Metropolitan University \\ Port Elizabeth
}

\section{SUMMARY}

Since 1994 South African courts have dealt with numerous cases where victims of crime have sued the State for its failure to protect them from criminal violation. This article explores these cases in order to ascertain the juristic nature of this liability and the criteria applied in ascertaining whether said liability exists under given circumstances. The author concludes that the legal remedy granted victims is based on the normal rules of the law of delict. Despite the constant reference by judges to constitutional imperatives, the matter is guided by the normal delictual criteria of reasonableness and public policy which, granted, have to be ascertained in deference to constitutional norms. The essential test has thus not changed since to the inception of the Constitution. Nevertheless, it appears that the courts have drawn fresh impetus from the Constitution in granting the claim of the victim of crime. South African courts have thus far shown opposition to the granting of punitive or constitutional damages to victims of crime though the possibility of the granting thereof in future has not been ruled out unequivocally.

\section{$1 \quad$ INTRODUCTION}

Since the inception of a constitutionally-based dispensation in 1994 South Africa has witnessed numerous cases in which its courts have dealt with instances of persons suing the State for its failure to protect them from criminal victimisation. Cases of this nature were not unknown in pre-1994 case law, but they have become more numerous since 1994. This article explores the body of case law that has developed around this emotive issue in order to ascertain the juristic nature of the liability and the criteria therefore. Minister of Safety and Security $v$ White is the latest in a series of cases dealing with the State's liability for the omission of its servants to

Unreported decision of the Eastern Cape Division, case number CA 98/2008. 
protect civilians from criminal attack; a distinct and identifiable body of germane case law has emerged in post-1994 South Africa. Landmark cases paved the way to the point where a case such as White is a routine feature in South Africa's legal landscape. It will be shown that the courts refer extensively to fundamental constitutional rights in granting these claims. The reluctance of South African courts to award punitive and constitutional damages in this context is also discussed.

\section{THE LATEST CASE}

Minister of Safety and Security $v$ White ${ }^{2}$ arose from a rape committed after the police had neglected to enforce a protection order ${ }^{3}$ when called upon to do so. The plaintiff (the respondent in the current case) was raped by her estranged husband, the target of said protection order. Kemp AJ in the East London Circuit High Court found the defendants ${ }^{4}$ jointly and severally liable for the damages of the rape victim based on the negligent police failure to enforce the protection order. Determination of quantum was left for a separate trial. The defendants/appellants then appealed - unsuccessfully to the Eastern Cape Division. The evidence showed that, in order to avoid confrontation, the respondent had previously allowed her husband to use her house as a base and to spend time there - though not actually live there contrary to the terms of the protection order, but she requested the police to enforce the order due to an escalation in his threatening behaviour, accompanied by forceful demands for money. The police arrived several hours later than they had undertaken to and ended up siding with the husband and telling the respondent that hers was, in fact, a civil case and that her ex-husband was not a threat to her safety. Much of the judgment deals with how a court ought to deal with credibility issues in conflicting evidence, with the respondent's version of events finally being accepted. The matter of causality was also raised and it was argued on behalf of the appellants that the ex-husband might still have been inclined to rape the respondent (and have the opportunity to do so) on that particular Tuesday even if the police intervention had taken place on the preceding Saturday as he might not (still) have been in custody on Tuesday. The court rejected this argument, accepting the most probable inference to be that he would not have raped her had the police taken positive action when called to the house - either because he would have been in custody or because he would have been discouraged by the fact that action had been taken or, at least, threatened. The court refused to accept that the damages suffered by the victim were too remote from the failure of the police because the ensuing violence inflicted on the victim was indeed a reasonably foreseeable consequence of the police failure under the given circumstances. Finally, the court rejected the contention that granting relief in cases of this nature might

2 Unreported decision of the Eastern Cape Division, case number CA 98/2008.

3 In terms of the Prevention of Family Violence Act 133 of 1993; however, the court deemed the order to have been made in terms of the Domestic Violence Act 116 of 1998 as the original had been re-stamped by the magistrate's court which issued it.

4 The second, third and fourth defendants were members of the police force. 
prove to be over-burdensome to the state on policy considerations, drawing support from the Carmichele and Van Duivenboden cases. ${ }^{5}$

\section{PRE-1994 CASE LAW}

Minister van Polisie $v$ Ewels ${ }^{6}$ is the pre-1994 locus classicus of a victim of crime successfully holding the state liable for his victimisation. The respondent sued the appellant on the basis that certain policemen had failed to prevent an assault on him in their presence. While the claim was expressly based on section 5(d) of the Police $\mathrm{Act}^{7}$ (which delegates the prevention of crime to the police), the court refused to accept that this statutory duty created civil liability for non-compliance per se - the court interpreted the legislation and found no express indication of such civil liability. The court fell back on traditional delictual discourse and based the liability of the state for the omission of the policemen on the legal - as opposed to purely moral - convictions of society; ${ }^{8}$ the decision was thus based on purely delictual principles.

\section{POST-1994 CASE LAW}

Fose $v$ Minister of Safety and Security ${ }^{9}$ - the first post-1994 case in which the subject matter of this article was canvassed - arose from an alleged assault suffered by the applicant at the hands of the police. Though this case does not deal with police inactivity in protecting ordinary people from criminal onslaught (but direct police brutality) it is relevant because the viability of a right to claim punitive or constitutional damages - in addition to delictual damages - for the infringement of fundamental rights in the interim Constitution received judicial attention. ${ }^{10}$ In the court a quo ${ }^{11}$ the respondent had successfully excepted to the claim for constitutional damages, contending that "an action for damages in the nature of constitutional damages does not exist in law, and an order for payment of damages does not qualify as appropriate relief contemplated in section 7(4)(a) of the interim Constitution". The Constitutional Court ${ }^{12}$ held that the term "constitutional damages" refers to a public law remedy existing in addition to normal delictual damages under private law. The aim is to vindicate the fundamental constitutional rights violated, deterring such assaults in future, punishing the state organs involved - thus fulfilling a punitive and preventative role - and also compensating the victim. The normal (delictual) common law remedies

\footnotetext{
These cases are discussed below in par 4.

19753 SA 590 (A).

7 of 1958. See also Dersley v Minister van Veiligheid en Sekuriteit [2000] 1 All SA 484 (T).

"(D)ie regsoortuiging van die gemeenskap verlang dat die late as onregmatig beskou behoort te word ..." - Minister van Polisie v Ewels supra 596.

19977 BCLR 851 (CC).

10 S 10 deals with the person's right to human dignity, while s 11 deals with the right to freedom and security of the person and $\mathrm{s} 13$ deals with the right to privacy.

11 Fose $v$ Minister of Safety and Security 19962 BCLR 232 W per Van Schalkwyk J.

12 The majority judgment was handed down by Ackermann J, Didcott J, Kriegler $\mathrm{J}$ and O'Regan J; each gave separate judgments, but all concurred in the final order.
} 
address only the last stated objective. The applicant's contention was that section $7(4)$ (a) of the interim Constitution ${ }^{13}$ created a public law right to claim constitutional damages. On the facts the court declined to make an award of constitutional damages in addition to the normal delictual awards, though not ruling out the possibility that in future and in appropriate circumstances such an award might find a place in South African law. ${ }^{14}$ In this instance normal damages would compensate the applicant sufficiently and the court doubted that history had proved that an award of constitutional damages would have much of a punitive effect. ${ }^{15}$ In order to be effective (in a punitive and preventative sense) such an award would have to be substantial, ${ }^{16}$ thus granting the victim a benefit in the nature of a windfall over and above normal damages and placing a heavy burden on the fiscus, something undesirable in a financially beleaguered country such as South Africa.

Despite the refusal to extend the existing law in this particular instance, the court stated:

"If necessary to do so, the courts may even have to fashion new remedies to secure the protection and enforcement of these all important rights."

\section{And}

"The South African common law of delict is flexible and under section 35(3) of the interim Constitution should be developed by the courts with 'due regard to the spirit, purport and objects' of Chapter 3".

The court doubted whether the distinction between private law and public law has much relevance today. The last quotation above and the gist of the judgment show clearly that the court did not have any problem with a delictual (private law) remedy being used on its own to redress a violation of the Bill of Rights. ${ }^{19}$ The court went on, however, to express its disapproval of

13 S 7(4)(a) reads: "When an infringement of or threat to any right entrenched in this Chapter is alleged, any person referred to in par (b) shall be entitled to apply to a competent court of law for appropriate relief, which may include a declaration of rights" (author's own emphasis).

14 See the discussion of this judgment in Stein "Constitutional Jurisprudence" 1997 Annual Survey of SA Law 4579 . Although the tendency of the judgment is negative regarding the awarding of constitutional damages generally, the judgment should not be understood to say that constitutional damages cannot ever be awarded.

15 Punitive damages are not unknown in SA law. In Salzmann v Holmes 1914 AD 471480483 punitive damages were awarded with reference to the rule in Roman-Dutch law that the sum awarded was originally in the form of a penalty and that ordinary verbal slander was still a crime. In South African Associated Newspapers Ltd v Yutar 19692 SA 442 A 458D-E the same principle was accepted without further consideration. In the case of damages for adultery it has been accepted that a punitive aspect is still present - Bruwer v Joubert 1966 3 SA 334 A 338C-D. It is submitted that these instances must be distinguished from Fose in so far as they did not deal with constitutional damages.

16 In this case the amount claimed for constitutional damages was R200 000, the normal (delictual) damages claimed amounting to R130 000.

17 Fose v Minister of Safety and Security 19977 BCLR 851 (CC) 862 par [19]. The "all important rights" refer to the Bill of Rights.

18 Fose $v$ Minister of Safety and Security 19977 BCLR 851 (CC) 882 par [58].

19 See also Fose $v$ Minister of Safety and Security 19977 BCLR 851 (CC) 883 par [60-61]. 
the use of an order of damages for a punitive purpose. ${ }^{20}$ The court referred with apparent approval to "the creative fashioning of constitutional remedies which do not sound in money"21 in suitable cases, but did not elaborate on the nature of these remedies as the current facts did not require this. ${ }^{22}$

In Dersley $v$ Minister van Veiligheid en Sekuriteit ${ }^{23}$ the plaintiff suffered a financial loss when he acted on an erroneous assurance given to him by the police that a particular vehicle was not stolen property. The court found that the police had acted negligently and the plaintiff's claim was granted. Part of the defence rested on allegations of the plaintiff's own negligence. Though the court in this instance found that the plaintiff had not, in fact, been negligent in accepting the word of the police that the vehicle had not been stolen, it appears from the gist of the judgment that the contributory negligence of the plaintiff - if proved - could have a bearing on the claim. As pointed out above, this case did not involve violent victimisation of the plaintiff; what the courts' attitude in this respect will be in the case of crimes of violence remains to be seen. It is suggested that courts should not allow the plaintiff's own negligence to defeat the claim of the victim of violent crime, based on the Constitutional guarantee that every person has the right to life, ${ }^{24}$ human dignity ${ }^{25}$ and freedom and security of the person. ${ }^{26}$ The fact that there is no direct reference to freedom from violence in the interim Constitution ${ }^{27}$ emphasises the importance which the legislators attached to this provision when drafting the final version of the Constitution. ${ }^{28}$ Holding his or her negligence against a victim of violence harks back to the era when rape trials had more to do with the previous promiscuity of the complainant than the actual behaviour of the perpetrator.

The landmark case of Carmichele $v$ Minister of Safety and Security (Centre for Applied Legal Studies intervening) ${ }^{29}$ arose from a serious assault

20 Fose $v$ Minister of Safety and Security 19977 BCLR 851 (CC) 889 par [70].

21 Fose $v$ Minister of Safety and Security 19977 BCLR 851 (CC) 890 par [74].

22 In keeping with Fose, the court in Dendy $v$ University of Witwatersrand, Johannesburg and others [2005] 2 All SA 490 (W) found the actio injuriarum to be sufficiently flexible to accommodate claims for damages arising from violations of fundamental constitutional rights. The court questioned the desirability of creating a separate constitutional delict exclusively to address breaches of fundamental rights. A case where constitutional damages were granted was MEC, Department of Welfare $v$ Kate [2006] 2 All SA 455 (SCA): the respondent claimed interest for the unreasonably long period between the application for a disability grant and the date she was notified of its approval - this interest would not normally be due as the debt was not yet payable. Interest was, however, awarded as constitutional damages ( $\mathrm{v}$ [33]) for the unreasonable delay in this case. It is submitted that if constitutional damages can be granted in a case where the law would not otherwise recognise a claim for damages, the question might well be asked if granting such a claim is not, in affect, punitive in nature; it is foreseen that the last word regarding the relationship between constitutional damages and punitive damages has not been uttered. [2000] 1 All SA 484 (T)

$\mathrm{S} 11$.

S 10.

$\mathrm{S} 12$

27 Constitution of the Republic of South Africa Act 200 of 1993. Referred to as the interim Constitution.

28 De Waal et al Bill of Rights Handbook (1998) 199.

29200110 BCLR 995 (CC); 20014 SA 938 (CC). 
suffered at the hands of an individual with a history of assault who had been granted bail on a charge of rape, despite the attempts of interested parties to persuade both police and prosecutor to oppose bail. The plaintiff had instituted action for alleged dereliction of duty by the latter persons. The High Court had granted absolution from the instance on the grounds that prima facie a duty of care had not been proved. This finding was upheld by the Supreme Court of Appeal. ${ }^{30}$ The Constitutional Court ${ }^{31}$ overturned the finding of absolution from the instance and referred the matter back to the High Court for trial. This time the plaintiff's claim met with success. ${ }^{32}$

The court considered the plaintiff's cause of action to be founded solely on delict arising from a breach of duty owed her by the police and/or the prosecutor, providing a causal link was proved between such breach and the injuries suffered.

The Constitutional Court was unambiguous regarding the fact that there was an obligation on all courts to develop the common law and to do so in keeping with the Constitution:

"(U)nder the Constitution there can be no question that the obligation to develop the common law with due regard to the spirit, purport and objects of the Bill of Rights is an obligation which falls on all of our courts including this Court."

However, the court emphasised that this duty was not taken lightly: ${ }^{34}$

"Moreover the issue in this case can hardly be described as an insignificant one, lying at an exotic periphery of the law of delict. On the contrary, the case raises issues of considerable importance to the development of the common law consistently with the values of our Constitution."

The court proceeded to consider in terms of the common law the basis of the legal duty to act and concluded that the duty to act was based on reasonableness, namely whether it would be reasonable to expect a party to have taken positive measures to prevent the injury. However, the Constitution now elaborated on this test: ${ }^{35}$

"(I)n determining whether there was a legal duty on the police officers to act, Hefer JA in Minister of Law and Order $v$ Kadir ${ }^{36}$ referred to weighing and the striking of a balance between the interests of parties and the conflicting interests of the community. This is a proportionality exercise with liability depending upon the interplay of various factors. Proportionality is consistent

30 Carmichele $v$ Minister of Safety and Security 20011 SA 489 (SCA).

31 The unanimous judgment was delivered by Ackermann and Goldstone JJ.

32 Carmichele $v$ Minister of Safety and Security 20032 SA 656 (C). See discussion below in this paragraph.

33 Carmichele $v$ Minister of Safety and Security (Centre for Applied Legal Studies intervening) 200110 BCLR 995 (CC); 20014 SA 938 (CC) 1006 par [34]. This is a paraphrase of $\mathrm{s}$ 39(2) of the Constitution.

34 Carmichele $v$ Minister of Safety and Security (Centre for Applied Legal Studies intervening) 200110 BCLR 995 (CC); 20014 SA 938 (CC) 1015 par [59].

35 Carmichele $v$ Minister of Safety and Security (Centre for Applied Legal Studies intervening) 200110 BCLR 995 (CC); 20014 SA 938 (CC) 1009 par [43-44].

$36 \quad 19951$ SA 303 (A) 318E-H. 
with the Bill of Rights, but that exercise must now be carried out in accordance with the 'spirit, purport and objects of the Bill of Rights' and relevant factors must be weighed in the context of a constitutional state founded on dignity, equality and freedom and in which government has positive duties to promote and uphold such values ... (T)he Bill of Rights entrenches the rights to life, ${ }^{37}$ human dignity ${ }^{38}$ and freedom and security of the person ... ${ }^{39}$ It follows that there is a duty imposed on the State and all its organs not to perform any act that infringes these rights" (author's own emphasis).

The court went on to adopt the reference in Osman $v$ United Kingdom ${ }^{40}$ to "a positive obligation on the authorities to take preventive operational measures to protect an individual whose life is at risk from the criminal acts of another individual."

The Constitutional Court thus supported the proposition that the Constitution recognises ${ }^{41}$ a legal duty of protection vesting in the state to protect individuals not only from the actions of the state's representatives, but also from the actions of other individuals. The breach of such duty can lead to the state being delictually liable to the victim.

In order to allay fears that this approach could lead to the state being delictually liable in every case where a person suffers the effect of a crime, the court went on to state: ${ }^{42}$

"Fears expressed about the chilling effect such delictual liability might have on the proper exercise of duties by public servants are sufficiently met by the proportionality exercise which must be carried out and also by the requirement of foreseeability and proximity ... A public interest immunity excusing respondents from liability that they might otherwise have in the circumstances of the present case, would be inconsistent with our Constitution and its values."

The court was thus extending a lifeline to the state to protect it from universal liability for the consequences of crime: the requirement of a causal link between the action or inaction on the one hand, and the injury suffered on the other hand, will be used to ensure that cases of state liability are kept in check.

\footnotetext{
S 11.

S 10.

$\mathrm{S} 12$.

29 EHHR 245305 par 115.
}

41 That this duty is recognised - and not actually created - by the Constitution is convincingly argued in Van der Walt "Horizontal Application of Fundamental Rights and the Threshold of the Law in View of the Carmichele Saga" 200319 SA Journal on Human Rights 517, where the author argues that it is actually SA Law of Civil Procedure - or the courts' interpretation thereof - which is at variance with constitutional imperatives and that a correct interpretation of the common law of delict would have led to the same ultimate outcome; in other words, the law of delict would have granted the victim's claim, but restrictions imposed by procedural law caused the protracted nature of the Carmichele litigation. The author's stance regarding the ability of the common law of delict to deal adequately with the victim's claim is born out in the minority judgment of Marais JA in Van Duivenboden's case - see discussion of this case in this paragraph (below).

42 Carmichele v Minister of Safety and Security (Centre for Applied Legal Studies intervening) 200110 BCLR 995 (CC); 20014 SA 938 (CC) 1012 par [49]. 
The following comment concerning this judgment sums up its

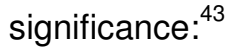

"(T)he judgment introduces a whole new dimension to the relationship between the state and its individual citizens, significantly strengthening the rights of ordinary people. The judgment is a demonstration both of the court's independence and of the value to ordinary people of our constitutional democracy."

The matter was then heard by the Cape Provincial Division ${ }^{44}$ for a decision on whether the state owed Carmichele a duty to exercise reasonable care in the prevention of crime on these particular facts and whether the requisite causal link was present. The court held that primary significance attached to the relevant constitutional imperatives. On the application of that test, the court found that the state owed Carmichele a legal duty to protect her against the risk of sexual violence perpetrated by the offender. The negligent failure to do so was unlawful.

It then became necessary to determine whether the requirement of causality had been satisfied. The court had to decide whether:

- Causality had to be determined by asking how the particular judicial officer who granted the offender bail would have decided the matter; or whether

- Causality had to be determined by asking how a reasonable court would have decided the matter.

The court elected to apply the second criterion - the objective approach deciding that a reasonable court apprised of the full facts would have denied bail. It then had to be determined whether the omissions of the servants of the state were closely enough linked to the harm suffered by Carmichele. Applying the test laid down in International Shipping Co (Pty) Ltd v Bentley, ${ }^{45}$ the court found that the link between the omissions and the harm was indeed sufficiently close and ordered the payment of damages. An appeal was dismissed by the Supreme Court of Appeal, the latter considering this to be a case where a "public law breach of duty can be transposed into a private law breach leading to an award for damages". ${ }^{46}$

Minister of Safety and Security $v$ Van Duivenboden ${ }^{47}$ was an appeal from a judgment of the Cape Provincial Division in which the respondent had successfully sued the appellant for damages. The matter arose from a shooting incident in which a certain Brooks shot and killed his wife and child, shooting and paralysing the respondent in the process. Brooks had a record of abusive and threatening behaviour of which the authorities were aware. In terms of legislation ${ }^{48}$ the Commissioner of Police may take steps to have a

43 Editorial "A Salutary Precedent" 20 August 2001 Business Day.

44 Carmichele $v$ Minister of Safety and Security 20032 SA 656 (C).

4519901 SA 680 (A) 701, where the court applied the causa sine qua non test.

46 Minister of Safety and Security $v$ Carmichele 20043 SA 305 (SCA) 321D-E.

20026 SA 431 (SCA).

$48 \mathrm{~S} 11$ of the Arms and Ammunition Act 75 of 1969 amended by the Arms and Ammunition Acts Amendment Act 117 of 1992. 
person declared unfit to possess a firearm if the latter shows inter alia, the intention to kill or injure anyone, or if his or her possession of a firearm is not in the interests of any person as a result of the mental condition or inclination to violence of the possessor of the firearm. For a considerable period before the respondent was shot, various police officers were in possession of information that reflected upon Brooks's fitness to be in possession of firearms.

The court ${ }^{49}$ pointed out that a negligent omission is unlawful only if it occurs in circumstances that the law regards as sufficient to give rise to a legal duty to avoid negligently causing harm. The existence of a legal duty does not, however, automatically lead to liability. Negligence is also required; the test being whether a reasonable person in the position of the defendant would not only have foreseen the harm, but would also have acted to avert it. Negligence is not inherently unlawful. Where the negligence manifests itself in a positive act it is presumed to be unlawful. The court endorsed the test for negligence propounded in Kruger $v$ Coetzee, ${ }^{50}$ namely whether a reasonable person in the position of the party concerned would not only have foreseen the harm, but would also have acted to avert it.

The court referred to Minister van Polisie $v$ Ewels. ${ }^{51}$ This was found to be in keeping with the approach followed in English law. However, the court emphasised that "the question to be determined is one of legal policy, which must perforce be answered against the background of the norms and values of the particular society in which the principle is sought to be applied". ${ }^{2}$ The Constitution serves as the supreme source of the norms and values of South African society. No norms conflicting with the Constitution are valid. The court labelled the Constitution "a system of objective, normative values for legal purposes". ${ }^{53}$ The court also acknowledged that a duty to prevent injury will more readily be placed on the state than on an individual as it is "the very business of a public authority or functionary to serve the interests of others". ${ }^{54}$ The court went on to say: ${ }^{55}$

"(I)t must also be kept in mind that in the constitutional dispensation of this country the state (acting through its appointed officials) is not always free to remain passive. The state is obliged by the terms of section 7 of the 1996 Constitution not only to respect but also to "protect, promote and fulfil the rights in the Bill of Rights" and section 2 demands that the obligations imposed by the Constitution must be fulfilled."

49 The majority judgment was delivered by Nugent JA, Howie JA, Heher AJA and Lewis AJA concurred. Marais JA gave a separate, but concurring judgment.

5019662 SA 428 (A) 430E-F.

51 (Where it was held that a negligent omission will be regarded as unlawful conduct when the circumstances of the case are of such a nature that the omission not only evokes moral indignation, but the legal convictions of the community require that it should be regarded as unlawful - Minister van Polisie v Ewels supra 597A-B). See par 3 above.

52 Minister of Safety and Security $v$ Van Duivenboden supra par [16].

53 Minister of Safety and Security $v$ Van Duivenboden supra par [17]

54 Minister of Safety and Security $v$ Van Duivenboden supra par [19].

55 Minister of Safety and Security $v$ Van Duivenboden supra par [20] 
The public accountability of the state is an important factor in determining whether a duty to prevent injury rests on the state. However, this accountability can be enforced in a variety of ways - enforcement is not limited to granting a delictual claim to the victim: ${ }^{56}$

"The norm of accountability, however, need not always translate constitutional duties into private law duties enforceable by an action for damages, for there will be cases in which other appropriate remedies are available for holding the state to account. Where the conduct in issue relates to questions of state policy, or where it affects a broad and indeterminate segment of society, constitutional accountability might at times be appropriately secured through the political process, or through one of the variety of other remedies that the courts are capable of granting."

Against this constitutional duty of protection, other factors must be weighed up: ${ }^{.7}$

"It might be that in some cases the need for effective government, or some other constitutional norm or consideration of public policy, will outweigh accountability in the process of balancing the various interests that are to be taken into account in determining whether an action should be allowed."

The court found that there were no external factors militating against the state's liability and also no means to enforce the state's liability other than by granting the respondent a delictual claim. It was shown above that in the Carmichele case the Constitution was generally considered to extend the delictual rights of the victim; in Van Duivenboden's case it was pointed out the Constitution can also restrict the victim's delictual rights in circumstances where an award of damages is deemed not to be the most suitable remedy; public policy will presumably be the determining factor.

The court then considered the issue of causation, following the criteria adhered to by the Cape Provincial Division in Carmichele's case ${ }^{58}$ finding a "direct and probable chain of causation between the failure of the police to initiate an enquiry into the fitness of Brooks to possess firearms ... and the shooting of the respondent. ${ }^{, 59}$

Marais JA based his concurring judgment purely on the law of delict, finding it unnecessary to refer to the Constitution and the concept of Constitutional accountability: ${ }^{60}$

"For all their" momentous and enormous historic, symbolic, legal and emotional significance and status as the supreme law, in my view, their existence has little bearing upon this particular case ...

I hesitate to accept unreservedly that the listing in the Bill of Rights of a right (whether it be a newly accorded right or a longstanding one) necessarily gives rise to the existence of a legal duty to act where none existed previously ...

Minister of Safety and Security $v$ Van Duivenboden supra par [21].

5 Minister of Safety and Security $v$ Van Duivenboden supra par [22].

Carmichele v Minister of Safety and Security 20032 SA 656 (C).

Minister of Safety and Security $v$ Van Duivenboden supra par [30].

Minister of Safety and Security $v$ Van Duivenboden supra par [32-34].

61 Marais JA referred also to the interim Constitution. 
I doubt that the accountability of which section 41(1)(c) of the Constitution speaks ('All spheres of government and all organs of State within each sphere must ... provide effective, transparent, accountable and coherent government for the Republic as a whole ...') can be regarded as prima facie synonymous with liability under the lex Aquilia for damages for omissions to act."

The South African Law Reform Commission ${ }^{62}$ has cited this judgment as authority for the recommendation that the positive duties resting on state officials to act ought to be set out in legislation. While private citizens have the right to remain passive when the constitutional rights of others are threatened, the state has a constitutional duty to act in order to protect such potential victims from harm. The Commission "recommends that positive duties be visibly imposed on public office bearers responsible for the investigation of sexual ${ }^{63}$ offence matters by way of the multi-disciplinary protocols". ${ }^{64}$ Such protocols can be amended as the situation changes. The judgment is also seen to "delineate more closely the relationship between the right to freedom from violence as entrenched in section 12(1)(c) of the Constitution and concomitant duties on the state to take steps to protect this right." ${ }^{65}$

The Supreme Court of Appeal subsequently granted the claim of a woman raped by a known dangerous criminal and serial rapist who had escaped from police custody in van Eeden $v$ Minister of Safety and Security, ${ }^{66}$ relying on the Constitutional Court judgment in the Carmichele case.

In Hamilton $v$ Minister of Safety and Security ${ }^{67}$ the Cape Provincial Division granted a claim to the victim of a shooting offence. The authorities had possessed information showing the perpetrator to be emotionally unsuitable to have a firearm licence. The facts of the case arose in September 1993 - before the passing of the interim Constitution. The court stated: ${ }^{68}$

"To my mind in September 1993 the community's legal convictions demanded that the police exercise reasonable care in the prevention of violent crimes ..."

In Minister of Safety and Security $v$ Souza de $\operatorname{Lima}^{69}$ the respondent successfully sued the appellant for damages after the police had issued a firearm licence ${ }^{70}$ to someone who had subsequently shot the respondent,

62 SA Law Reform Commission December 2002 Sexual Offences Report Project 107.

63 It is to be the borne in mind that the Report deals specifically with sexual offences, but bearing also in mind that the Van Duivenboden case did not deal with sexual offences, it is submitted that the recommendations of the SA Law Reform Commission ought not to be limited to sexual offences, to the exclusion of other offences.

SA Law Reform Commission December 2002 Sexual Offences Report Project 10730.

Combrinck and Barday "Beyond Carmichele: Developing the Right to Freedom from Violence" (September 2002) 6/1 Gendernews (July 2006) http://www.communitylawcentre. org.za/gender/gendernews2002/2002_1_beyond.php.

6620031 SA 389 (SCA).

6720037 BCLR 723 (C) confirmed in Minister of Safety and Security v Hamilton 20042 SA 216 (SCA).

68 Hamilton $v$ Minister of Safety and Security supra 741 par [32].

69 [2006] 4 All SA 433 (SCA).

70 In terms of the Arms and Ammunition Act 75 of 1969. 
leaving him paraplegic. The High Court found that the police had been negligent, and that this was a direct cause of the respondent's injury. On appeal, the negligence of the police was confirmed. The Commissioner of Police had issued a special order which set out the factors which had to be considered when determining whether an applicant was fit to possess a firearm. It was found that the police officer who had interviewed the relevant person for a firearm licence did not properly understand his duties in this regard. The application form showed that person had previously been charged with assault and this should have prompted the police officer to conduct a proper interview to investigate the person's history fully - this omission amounted to negligence.

\section{CONCLUSION}

It is clear that South African courts do not shy away from holding the state liable for the inactivity of its representatives in preventing criminal victimisation in appropriate instances. The legal remedy granted victims is based on the normal rules of the law of delict. Despite the constant reference to constitutional imperatives - arising from public law thus - South African courts are not overly concerned with the traditional distinction between public and private law, confirming that law of delict - like all areas of law - is guided and developed in keeping with the requirements of the Constitution. In a nutshell, the whole matter is guided by the criterion of reasonableness which is informed by constitutional norms. The essential test remains the same as it has been for centuries: the boni mores, the legal convictions of the community, now guided also by the Constitution - as stated (over three decades ago): "the tempora et mores of today, not of yesteryear". ${ }^{71}$ Although the claim of the victim is firmly grounded in the law of delict and it can be argued - strongly - that the copious references made to the Constitution are superfluous, it does, however, seem as if the courts have drawn fresh impetus from the Constitution in being more willing to find in favour of victims of crime and to acknowledge the existence of a duty to act resting on the forces of law and order. It is submitted that this is a tendency that is to be welcomed under the circumstances currently prevailing in South Africa.

A limit to the liability of the state is to be found in the normal rules of causation - once again, this is in keeping with the everyday application of the law of delict. What the role of the plaintiff's own negligence should be in cases of violent criminal victimisation has yet to be determined by the courts.

South African jurisprudence has thus far shown itself to be opposed to the granting of punitive or constitutional damages to victims of crime though the possibility of the granting thereof in future has not been ruled out unequivocally. It seems that the reluctance of the courts in this respect is to be found in the great cost (in monetary terms) to the state which could lead to the non-availability of funds for other worthy causes - there does not seem to be any objection on grounds of legal principle.

71 Publication Control Board v Gallo (Africa) Ltd 19753 SA 556 (A) 683. 
Thus the recent body of case law dealing with victims of crime suing the state for its inactivity has created a useful body of precedent, but has not reinvented any juridical wheel. However, a body of precedent has developed - and presumably, will continue developing - that will serve as a useful guide to the legal community. Considering the increasing emphasis that is being placed by the South African legal system on the doctrine of restorative justice $^{72}$ - with its emphasis on the rights and role of the victim of crime in the criminal justice process - it is foreseen that interest in all aspects of the legal position of the victim of crime will continue growing.

72 See Von Bonde "Restorative Justice: Bringing Back the Pillory?" 2008 Obiter 133. 